это позволяет снизить премию за системный риск и инструмент становится доступнее для потребителя.

$$
* * *
$$

1. Гражданский кодекс Российской Федерации (часть первая)" от 30.11.1994 N 51-Ф3 [Интернет источник] СПС Консультант Плюс // (Режим доступа http://www.consultant.ru/document/cons_doc_LAW_5142/) (Дата обращения 03.04.2021);

2. Федеральный закон «О внесении изменений в Федеральный закон«О рынке ценных бумаг» и отдельные законодательные акты Российской Федерации» от 31 июля 2020 г. № 306-Ф3 [Интернет источник] СПС Консультант Плюс // (Режим доступа http://www.consultant.ru/document/cons_doc_LAW_34237/) (Дата обращения 03.04.2021)

3. Федеральный закон «О привлечении инвестиций с использованием инвестиционных платформ и о внесении изменений в отдельные законодательные акты Российской Федерации» от 2 августа 2019 г. № 259-Ф3 [Интернет источник] СПС Консультант Плюс // (Режим доступа http://www.consultant.ru/document/cons_doc_LAW_75832/) (Дата обращения 03.04.2021)

4. Федеральный закон "Об инвестиционных фондах" от 29.11.2001 N 156-ФЗ (последняя редакция) [Интернет источник] СПС Консультант Плюс // (Режим доступа http://www.consultant.ru/document/cons_doc_LAW_34237/) (Дата обращения 03.04.2021)

5. Федеральный закон "О Центральном банке Российской Федерации (Банке России)" от 10.07.2002 N 86-Ф3 (последняя редакция) [Интернет источник] СПС Консультант Плюс // (Режим доступа: http://www.consultant.ru/document/cons_doc_LAW_19671/ ) (Дата обращения 03.04.2021);

6. Федеральный закон «Об инвестировании средств для финансирования накопительной части трудовой пенсии» от 24 июля 2002 г. № 111-Ф3 [Интернет источник] СПС Консультант Плюс // (Режим доступа http://www.consultant.ru/document/cons_doc_LAW_34457/) (Дата обращения 03.04.2021)

7. Федеральный закон "О рынке ценных бумаг" от 22.04.1996 N 39-Ф3 (последняя редакция) [Интернет источник] СПС Консультант Плюс // (Режим доступа httphttp://www.consultant.ru/document/cons_doc_LAW_10148/) (Дата обращения 03.04.2021);

8. Федеральный закон "Об инвестиционной деятельности в Российской Федерации, осуществляемой в форме капитальных вложений" от 25.02.1999 N 39-ФЗ (последняя редакция) [Интернет источник] СПС Консультант Плюс // (Режим доступаhttp://www.consultant.ru/document/cons_doc_LAW_22142/) (Дата обращения 03.04.2021);

9. Основные направления развития финансового рынка Российской Федерации на период 2019 2021 годов Банк России. М., 2019 // https://cbr.ru/content/document/file/71220/main_directions.pdf

\title{
Меркель Е.А. \\ Проблема в понимании состава административного правонарушения за неисполнение законными представителями несовершеннолетних обязанностей по содержанию и воспитанию несовершеннолетних ФГАОУ ВО «Южно-Уральский государственный университет (НИУ)» (Россия, Челябинск)
}

doi: $10.18411 / \mathrm{sr}-10-04-2021-81$

\section{Аннотация}

В статье анализируется состав административного правонарушения за неисполнение законными представителями несовершеннолетних обязанностей по содержанию и воспитанию несовершеннолетних, предусмотренного ст. 5.35 Кодекса Российской Федерации об административных правонарушениях. Рассматриваются недостатки действующей редакции ст. 5.35 Кодекса Российской Федерации об административных правонарушениях, а также вопрос понимания различных подходов в восприятии и понимании ненадлежащего исполнения законными представителями несовершеннолетних обязанностей по содержанию и воспитанию несовершеннолетних.

Ключевые слова: Кодекс Российской Федерации об административных правонарушениях, административные правонарушения, административная ответственность, законные представители, несовершеннолетние. 


\section{Abstract}

The article analyzes the composition of an administrative offense for non-fulfillment by legal representatives of minors of the duties for the maintenance and education of minors, provided for in article 5.35 of the Code of the Russian Federation on administrative offenses. The article deals with the shortcomings of the current version of article 5.35 of the Code of administrative offences of the Russian Federation, as well as the issue of understanding different approaches to the perception and understanding of improper performance by legal representatives of minors of duties for the maintenance and upbringing of minors.

Key words: Code of the Russian Federation on administrative offences, administrative offences, administrative liability, legal representatives, minors.

Кодекс Российской Федерации об административных правонарушениях от 30.12.2001 № 195-Ф3 (далее КоАП РФ) предусматривает ответственность за «Неисполнение родителями или иными законными представителями несовершеннолетних обязанностей по содержанию и воспитанию несовершеннолетних», предусмотренная ст. 5.35 КоАП РФ. Рассматриваемая статья состоит из 3 частей, но наше внимание будет остановлено на ч. 1 данной статьи.

Состав каждого административного правонарушения включает в себя четыре элемента: объект, объективная сторона, субъект, субъективная сторона. Исходя из анализируемой статьи, по общим правилам, объектом правонарушения являются права несовершеннолетних; объективная сторона представляет собой совокупность признаков, характеризующих внешнюю сторону состава правонарушения (общественно опасное деяние в форме действия или бездействия; общественно опасные последствия; причинная связь между деянием и общественно опасными последствиями; время, место и иные обстоятельства, при которых было совершено противоправное деяние; приемы и средства совершения правонарушения); субъект согласно ст. 25.3 КоАП РФ родители, усыновители, опекуны или попечители; субъективная сторона - психическое и интеллектуальное (сознательно-волевое) отношение правонарушителя к совершенному деянию и его последствиям (самое главное в данном определении будет умысел или неосторожность). Возможно, с данным трактованием элементов состава правонарушения многие не согласятся, но остановимся на этом анализе.

В ст. 63 Семейного кодекса Российской Федерации от 29.12.1995 N 223-Ф3 (далее СК РФ) закреплено, что родители имеют право и обязаны воспитывать своих детей. Право на воспитание ребенка есть личное неотъемлемое право каждого родителя. Родители несут ответственность за воспитание и развитие своих детей. Они обязаны заботиться об их здоровье, физическом, психическом, духовном и нравственном развитии; обеспечить им получение основного общего образования, а также защищать права и интересы своих детей. Все эти обязанности закреплены в статьях 63-65 СК РФ. Ответственность за воспитание и развитие детей общая и обязательная для обоих родителей, где бы они ни находились. Временная передача родителями своих детей на воспитание родственникам, посторонним лицам либо в одно из детских учреждений не освобождает родителей от ответственности за воспитание и развитие детей. Обязанности по воспитанию детей родители и лица, их заменяющие, несут до совершеннолетия ребенка. Данная норма основывается на нормах международного права.

В нормах СК РФ и КоАП РФ дано разъяснение понятия субъекта правонарушения, предусмотренного ст. 5.35 КоАП РФ, а именно законного представителя. С субъективной стороной правонарушения также не возникает вопросов, так как вина в форме умысла очевидна, то есть лицо осознавало степень противоправного деяния, выраженного в неисполнении своих обязанностей и 
предвидело наступление каких-либо последствий (например, родители не оформили малолетнему ребенку документы, подтверждающие его личность, в результате чего малолетний не может посещать дошкольное учреждение, получать соответствующее медицинское лечение). Вина же в форме неосторожности, характеризует ненадлежащее исполнение возложенных по закону обязанностей, то есть лицо, сознательно допускало совершение противоправного деяния, но исключало наступление каких-либо последствий.

Ненадлежащее исполнение обязанностей законных представителей по воспитанию и обучению несовершеннолетних может выражаться и в злоупотреблении правом. В п. 16 Постановления Пленума Верховного Суда от 14.11.2017 № 44 «O практике применения судами законодательства при разрешении споров, связанных с защитой прав и законных интересов ребенка при непосредственной угрозе его жизни или здоровью, а также при ограничении или лишении родительских прав» указано, что злоупотреблением родительскими правами является использование этих прав в ущерб интересов детей [3].

Что касается объекта и объективной стороны правонарушения, то имеется ряд вопросов, которые мы попробуем разобрать, в связи с чем, остановимся на этом более подробно.

Ранее мы давали общее понятие объекта и объективной стороны правонарушения, то есть это права несовершеннолетних и совокупность признаков, характеризующих внешнюю сторону состава правонарушения. Сами права несовершеннолетних закреплены в главе 11 СК РФ, но помимо этого они частично раскрываются в ст. 63 СК, несмотря на то, что данная статья раскрывает обязанности родителей. Исходя из этого, можно предположить, что названный нами объект правонарушения это узкое понятие. Попробуем сформулировать понятие объекта правонарушения, которое раскроет его максимально полно. И так, объектом правонарушения, предусмотренного ст. 5.35 КоАП РФ являются общественные отношения, направленные на реализацию и защиту прав и законных интересов несовершеннолетних со стороны законного представителя [2]. При этом, к административной ответственности по ч. 1 ст. 5.35 КоАП РФ можно привлечь законных представителей только за нарушение одного имущественного права - права на содержание, хотя в ст. 60 СК РФ достаточно многообразно сформулированы имущественные права несовершеннолетних [1].

С практической точки зрения, возникает трудность с определением объективной стороны правонарушения, так как деяние родителей (иных законных представителей) несовершеннолетних может быть представлено в форме действия (ненадлежащее исполнение обязанностей по воспитанию и содержанию несовершеннолетнего) или бездействия (неисполнение данной обязанности).

Объективная сторона в форме бездействия, говорит о конкретных правонарушениях, то есть об отсутствии участия законных представителей в воспитательном процессе несовершеннолетнего, реализации, защите прав и законных интересов несовершеннолетних.

Говоря о такой форме как действие, то осуществляя процесс воспитания, родители не вправе причинять вред физическому и психическому здоровью детей, их нравственному развитию. Способы воспитания детей должны исключать пренебрежительное, жестокое, грубое, унижающее человеческое достоинство обращение, оскорбление или эксплуатацию детей (п. 1 ст. 65 СК РФ). Таким образом, любое отступление от этих правил, закрепленных законодательно, является частным случаем ненадлежащего исполнения своих обязанностей по воспитанию ребенка.

Одним из последствий неисполнения родителями или иными законными представителями несовершеннолетних обязанностей по воспитанию несовершеннолетних является безнадзорность ребенка. Безнадзорность 
несовершеннолетнего приводит к виктимизации, так как вероятность становления жертвой правонарушения или преступления у таких детей возрастает [4] .

Помимо виктимизации в отношении несовершеннолетнего, возрастает вероятность совершения правонарушения непосредственно несовершеннолетним. Что также является объективной стороной правонарушения, предусмотренного ст. 5.35 КоАП РФ, так как чаще всего это выражается в форме действия и чуть реже в форме бездействия со стороны законных представителей.

Федеральное законодательство позволяет регионам формировать своё, областное или краевое законодательство об административной ответственности. Такое региональное формирование административной ответственности на наш взгляд, детализирует обязанность родителей воспитывать своих детей, заботиться о них. Так, согласно ч. 3 ст. 14.1 Федерального закона от 24.07.1998 № 124-Ф3 «Об основных гарантиях прав ребенка» региональное законодательство наделяется правом устанавливать меры по недопущению нахождения детей (лиц, не достигших возраста 18 лет) в ночное время в общественных местах [5].

Такое законодательство есть в Москве, Санкт-Петербурге, Краснодарском крае и многих других регионах страны. Законом Санкт-Петербурга от 31.05.2010 № 273-70 «Об административных правонарушениях в Санкт-Петербурге» предусмотрена ответственность за попустительство нахождению несовершеннолетних в общественных местах в ночное время без сопровождения родителей или лиц, их заменяющих (ст. 8_2). Схожая норма содержится в законодательстве Ленинградской области и других регионов страны.

Рассматривая законы Челябинской области, заметим, что есть закон Челябинской области № 125-30 от 28 ноября 2002 г. «О системе профилактики безнадзорности и правонарушений несовершеннолетних в Челябинской области» (ст. 21-1) где определена обязанность родителей не допускать пребывания несовершеннолетних в общественных местах в определенное время суток без сопровождения родителей. Исходя из этого, если подобные действия (бездействие) родителей являются следствием неисполнения или ненадлежащего исполнения родительских обязанностей, то привлечение к административной ответственности должно осуществляться по ч. 1 ст. 5.35 КоАП РФ. Хотя ранее, в законе Челябинской области от 02.06.2010 № 584 - 30 «Об административных правонарушениях в Челябинской области» была ст. 14 подразумевающую ответственность родителей (лиц, их заменяющих) за нахождение несовершеннолетних в возрасте до 16 лет с 22 часов до 06 часов, в возрасте от 16 и до 18 лес с 23 часов до 06 часов в общественных местах без сопровождения законных представителей. Административное наказание по данной статье в виде штрафа от 500 рублей до 30000 рублей применялось к физическим, должностным и юридическим лицам. Также в данной статье имелась ч. 2 подразумевающая ответственность должностных и юридических лиц, за нахождение несовершеннолетних в любое время суток на объектах осуществляющих реализацию товаров сексуального характера, а также осуществляющих реализацию только алкогольной продукции (кафе, бары рестораны). Ключевыми словами в данной статье было «несоблюдение требований к обеспечению мер по содействию физическому, интеллектуальному, психическому, духовному и нравственному развитию детей и предупреждению причинения им вреда». В декабре 2015 года в данный закон были внесены изменения, в результате чего ст.14 была исключена.

Сравнивая нормы ст. 5.35 КоАП РФ (административное наказание в виде предупреждения или административного штрафа в размере от 100 рублей до 500 рублей) и ст. 14 закона Челябинской области № 584 - 30 (далее Закон № 584 - 30) (будем считать ее действующей) мы заметим очевидную разницу не только в размере административного наказания, но и в должностных лицах, уполномоченных рассматривать данные правонарушения. В первом случае это комиссии по делам несовершеннолетних и защите их прав (далее КДН и ЗП), а во втором случае это 
мировой суд. Сам факт назначения мировым судьей, даже самого минимального наказания по ст. 14 Закона № 584 - 30 в виде штрафа в размере 500 рублей имеет большее психологическое воздействие на правосознание правонарушителя.

На наш взгляд, забота о здоровье уже предполагает надзор и контроль за ребенком, недопущение оставления несовершеннолетнего без присмотра взрослых, когда он может быть травмирован или подвергнут вовлечению в употребление спиртных напитков и т. п. Забота о психическом, духовном и нравственном развитии предусматривает определение родителями мест времяпрепровождения детей, мероприятий, которые они посещают, увлечений, которым уделяют внимание, исходя из правовых и моральных норм, ценных в обществе. Полагаем, что обязанность родителей (иных законных представителей) несовершеннолетних по недопущению нахождения детей в определенных местах и в определенное время, установленная региональным законодательством, является частью обязанности указанных лиц по надлежащему воспитанию несовершеннолетних. Об этом говорит законодатель, как на региональном уровне, так и на федеральном.

Само правонарушение, в практическом понимании, несоразмерно имеющемуся наказанию и не охватывает в полном объеме нарушение. С одной стороны, фабула ч. 1 ст. 5.35 КоАП РФ предусматривает ответственность законных представителей несовершеннолетних за неисполнение обязанностей по содержанию, воспитанию, обучению, защите прав и интересов несовершеннолетних, а с другой стороны, если мы рассматриваем правонарушение совершенное несовершеннолетним в возрасте до 16 лет, характеризующегося с положительной стороны, воспитывающегося в благополучной семье, где законные представители выполняют свои обязанности по воспитанию детей, то мы не усматриваем в их действиях состава правонарушения, предусмотренного ч. 1 ст. 5.35 КоАП РФ, так как для наличия состава необходима совокупность признаков нарушения.

Еще одной сложностью в определении данного состава правонарушения, является то, что правонарушение относится к категории длящихся. Датой его совершения считается день выявления факта (события) правонарушения, но период его совершения может иметь длительный характер. Ответственности по данной статье подлежат родители, а также иные законные представители несовершеннолетних (опекуны и попечители, должностные лица администрации детского учреждения, в котором находится несовершеннолетний, должностные лица органов опеки и попечительства, если несовершеннолетний не имеет опекунов и попечителей и не устроен в детское учреждение).

Основанием для привлечения к административной ответственности по данной статье являются действия или бездействие лица, выражающиеся в неисполнении или ненадлежащем исполнении им обязанностей по содержанию, воспитанию, обучению, защите прав и интересов несовершеннолетних детей, что может повлечь совершение детьми административных правонарушений и уголовно наказуемых деяний, уклонение их от учебы, бродяжничество, иные антиобщественные действия. Правонарушением считается сам факт неисполнения или ненадлежащего исполнения предусмотренных законом обязанностей, независимо от наступления каких-либо вредных последствий.

$$
* * *
$$

1. Алексанян А.М. Ответственность родителей за ненадлежащее воспитание детей // Вестник Российского экономического университета им. Г.В. Плеханова. 2015. № 1/2 (11). С. 115-123.

2. Банщикова С.Л. Личные и имущественные права несовершеннолетних как объект правонарушения, предусмотренного ст. 5.35 КоАП РФ // Современные научные исследования: теория методология практика : сб. науч. тр. / под ред. А.И. Барановского. Омск : АНО ВПО «Омский экономический институт», 2011. Вып. 5. С. 235-242.

3. Януш Е.В., Казарин В.Н. Административная ответственность за неисполнение родителями или иными законными представителями несовершеннолетних обязанностей по содержанию и воспитанию несовершеннолетних // Сибирский юридический вестник. Иркутск : «Иркутский государственный университет», 2019. Вып. 4 (87). С. $42-47$. 
4. Банщикова С.Л. Административная ответственность за неисполнение родителями или иными законными представителями несовершеннолетних обязанностей по их содержанию // Диссертация на соискание ученой степени к.ю.н. Омск. 2016. [Электронный ресурс]. - Режим доступа: https://lawbook.online/administrativnoe-pravo-rossii-kniga/osobennosti-sostavov-administrativnyih79728.html

5. Комендантский час для несовершеннолетних подростков [Электронный ресурс]. - Режим доступа: http://semeinoe-pravo.net/komendantskij-chas-dlya-nesovershennoletnih/

\section{Павлова Е.В. \\ Отдельные аспекты определения административной ответственности в Российской Федерации на современном этапе}

Орловский юридический институт МВД России имени В.В. Лукьянова (Россия, Орел)

doi: $10.18411 / s r-10-04-2021-82$

\section{Аннотация}

Осуществлен анализ теоретических и правовых основ определения административной ответственности в Российской Федерации в современный период развития государственности, сформулированы предложения о необходимости законодательного закрепления дефиниции административная ответственность.

Ключевые слова: правовое закрепление, административная ответственность, административное правонарушение.

\section{Abstract}

The analysis of the theoretical and legal foundations of the definition of administrative responsibility in the Russian Federation in the modern period of the development of statehood is carried out, proposals are formulated on the need for legislative consolidation of the definition of administrative responsibility.

Keywords: legal consolidation, administrative responsibility, administrative offense.

В современном мире назрела острая необходимость изучения и определения понятия «административная ответственность». Данное понятие является сложной и часто изучаемой категорией, которая нуждается в теоретическом осмыслении и правовом закреплении .

Согласно статье 2.3. Кодекса об административных правонарушениях Российской Федерации [1] административной ответственности подлежит лицо, достигшее к моменту совершения административного правонарушения возраста шестнадцати лет. В пункте втором этой же статьи говорится о том, что, с учетом всех конкретных обстоятельств, комиссией по делам несовершеннолетних лицо от шестнадцати до восемнадцати лет может быть освобождено от административной ответственности, но с применением к гражданину иной меры воздействия, предусмотренной федеральным законодательством о защите прав несовершеннолетних.

Проанализировав статью, можно прийти к выводу о том, что данная норма тесно перекликается с нормами других отраслей права, например, с уголовным. Так, Уголовный Кодекс [2] устанавливает общий возраст уголовной ответственности с шестнадцати лет, а за совершение отдельных видов преступлений даже с четырнадцати. Также можно привести пример и в сфере гражданских правоотношений, где имущественную ответственность за причинение того или иного вреда несут с четырнадцати до восемнадцати лет. Трудовой Кодекс [3] также устанавливает возраст лица, с которым можно заключить трудовой договор, который также составляет шестнадцать лет. 